\title{
Overall equipment effectiveness improvement through total productive maintenance in assembly cell
}

\begin{abstract}
The Overall Equipment Effectiveness (OEE) is an established method to monitor and improve the effectiveness of manufacturing processes. OEE is frequently used as a key metric in Total Productive Maintenance (TPM) and Lean Manufacturing environment. This paper focuses on the OEE measurement of the assembly line of steering gear in an automotive company (AGR Sdn Bhd) through the implementation of TPM. The average OEE measurement before implementation of TPM is $52.21 \%$ which is below the company's target. The company used reactive maintenance, which is inherently "wasteful and ineffective. After the implementation of TPM, the OEE performance for the assembly department improved to $70.21 \%$. The result shows that machine down time directly influence the OEE. The implementation of TPM enables the company to change their maintenance practices from reactive to proactive. The average availability percentage is $80.34 \%$ and performance efficiency average is $87.99 \%$. This has directly contributed to a lower overall OEE performance compared to world standard. The rate of quality is maintained at an average of $99.54 \%$.
\end{abstract}

Keyword: Availability; Overall Equipment Effectiveness (OEE); Performance efficiency; Rate of quality; Total Productive Maintenance (TPM) 